(c) American Dairy Science Association, 2007.

\title{
Severity of Ruminal Acidosis in Primiparous Holstein Cows During the Periparturient Period
}

\author{
G. B. Penner, ${ }^{\star} \dagger$ K. A. Beauchemin,$t^{1}$ and T. Mutsvangwa* \\ ${ }^{*}$ Department of Animal and Poultry Science, University of Saskatchewan, Saskatoon, S7N 5A8, Canada \\ †Agriculture and Agri-Food Canada, Research Center, Lethbridge, Alberta, T1J 4B1, Canada
}

\begin{abstract}
The objectives of this study were: 1 ) to determine the effect of providing additional prepartum concentrate on the occurrence and severity of ruminal acidosis (RA) and lactational performance during the periparturient period in primiparous cows; and 2) to characterize the occurrence and severity of RA during the periparturient period. We hypothesized that providing additional concentrate prepartum would reduce postpartum RA. Fourteen ruminally cannulated Holstein heifers were paired by expected calving date and body condition score. The heifers were assigned to 1 of 2 prepartum feeding regimens: 1) a control treatment consisting of a far-off diet (forage:concentrate, $\mathrm{F}: \mathrm{C}=80: 20$ ) fed from $\mathrm{d}-60$ to $\mathrm{d}-25$ and a close-up $\operatorname{diet}(\mathrm{F}: \mathrm{C}=54: 46)$ fed from d -24 until parturition; or 2) a high-concentrate (HC) feeding program consisting of 4 prepartum diets, HC-1 (F:C = 68:32) fed from d -60 to d $-43, \mathrm{HC}-2$ (F:C = 60:40) fed from $d-42$ to $d-25, \mathrm{HC}-3(\mathrm{~F}: \mathrm{C}=52: 48)$ fed from $\mathrm{d}-24$ to $\mathrm{d}-13$, and $\mathrm{HC}-4(\mathrm{~F}: \mathrm{C}=46: 54)$ fed from $\mathrm{d}-12$ until parturition. All cows received the same lactation diet postpartum. Ruminal $\mathrm{pH}$ was measured continuously from $\mathrm{d}-5$ to $\mathrm{d}+5$, and for 3 consecutive days starting on $\mathrm{d}+17 \pm 1.2, \mathrm{~d}+37 \pm 1.4$, and $\mathrm{d}+58 \pm 1.5$ relative to parturition using an indwelling ruminal $\mathrm{pH}$ system. Ruminal acidosis was considered to occur when ruminal $\mathrm{pH}$ was $<5.8$ (total RA). Ruminal acidosis was further partitioned into: 1) mild $\mathrm{RA}(5.8>$ ruminal $\mathrm{pH}$ $>5.5)$, 2) moderate $\mathrm{RA}(5.5>$ ruminal $\mathrm{pH}>5.2)$, and 3 ) acute RA (ruminal $\mathrm{pH}<5.2$ ). Feeding additional concentrate prepartum did not reduce postpartum RA. In fact, cows fed the HC treatment had more daily episodes of acute RA than cows fed the control treatment. Day relative to parturition affected the occurrence and severity of RA; RA increased following parturition and was sustained thereafter. The DM intake during the last $5 \mathrm{~d}$ of gestation was lower for cows fed the HC treatment compared with cows fed the control
\end{abstract}

Received June 4, 2006.

Accepted August 31, 2006.

${ }^{1}$ Corresponding author: beauchemink@agr.gc.ca treatment, but lactational performance was not affected. We conclude that, under the conditions imposed, feeding additional concentrate prepartum does not reduce postpartum RA. Furthermore, the incidence and severity of RA increases immediately postpartum, emphasizing the need to develop and implement feeding strategies that reduce this risk.

Key words: ruminal acidosis, dairy cow, transition period

\section{INTRODUCTION}

Transition cows undergo drastic metabolic and hormonal changes in response to increased nutrient demands of the growing fetus, parturition, and the onset of lactation (Grummer, 1995; Dann et al., 1999; Drackley, 1999). The majority of these changes increase the cow's susceptibility to metabolic disorders immediately before and after parturition (Drackley, 1999). In first-lactation heifers, body growth also competes for nutrients (NRC, 2001). As parturition approaches, DMI decreases (Hayirli et al., 2003) but nutrient requirements increase (NRC, 2001). To account for the reduction in DMI as parturition approaches, various nutritional strategies have been developed. One particular strategy is to increase the dietary energy density by including higher proportions of concentrate $(\mathrm{McNa}-$ mara et al., 2003; Rabelo et al., 2003). However, feeding a diet with low NDF content often results in a greater magnitude of DMI depression near parturition (Hayirli et al., 2003; Rabelo et al., 2003). Positive benefits of supplying more concentrate prepartum include improved growth of ruminal papillae (Dirksen et al., 1985) and changes in ruminal microflora (Tajima et al., 2000) such that the rumen is better adapted to the energydense diet fed postpartum (NRC, 2001). Postpartum diets often contain high levels of fermentable carbohydrate and low levels of fiber to maximize energy intake. Large changes in dietary composition, which occur at parturition, increase the risk of ruminal acidosis (RA; Nocek, 1997). This problem may be exacerbated in primiparous cows when compared with multiparous cows because primiparous cows have not had previous longterm exposure to a highly fermentable lactation diet. 
Krause and Oetzel (2006) investigated the incidence of RA postpartum using clinical observation data and reported that primiparous cows had a higher risk of RA than multiparous cows.

Gröhn and Bruss (1990) conducted a large epidemiological study $(>60,000$ cows $)$ and found that the greatest number of cases of RA were diagnosed during the first few months after calving. Although Gröhn and Bruss (1990) have characterized the occurrence of RA throughout the production cycle, only one spot sample of ruminal fluid was collected for ruminal $\mathrm{pH}$ measurement, and $\mathrm{pH}$ paper was used as an indicator of low ruminal $\mathrm{pH}$. As a result, only qualitative assessments were made based on irregular sampling; thus, many cases of subacute RA would have gone undetected. Furthermore, Gröhn and Bruss (1990) did not report any dietary information. In contrast, Krause and Oetzel (2006) conducted a review of subacute RA and reported that the risk for RA increases with increasing DIM, corresponding to increasing DMI.

To understand ruminal $\mathrm{pH}$ dynamics during the periparturient period, it is important to comprehensively measure ruminal $\mathrm{pH}$ daily and relate the results to dietary treatment. Previously, the lack of equipment available for continuous ruminal $\mathrm{pH}$ measurement in unrestrained cows limited measurements in transition cows. However, Penner et al. (2006) developed a new system capable of continuous ruminal $\mathrm{pH}$ measurement in unrestrained cattle. This system can characterize ruminal $\mathrm{pH}$ in applications in which continuous measurement was previously not feasible. The first objective of this study was to determine the effect of additional prepartum concentrate allocation on postpartum RA and lactational performance. The second objective was to characterize the occurrence and severity of RA in primiparous Holstein cows during the periparturient period. We hypothesized that the occurrence and severity of RA would increase postpartum, but feeding additional concentrate prepartum would ameliorate postpartum RA.

\section{MATERIALS AND METHODS}

\section{Experimental Design and Animals}

Eighteen Holstein heifers were used in a completely randomized design with 2 dietary treatments. Heifers, rather than multiparous cows, were used in this study because few published studies have examined feeding strategies to transition heifers from a pregnant nonlactating state to a nonpregnant lactating state. Furthermore, the inclusion of parity as an additional factor in the experiment would have reduced the statistical power had an interaction between diet and parity occurred. The experiment began in March 2005 and ended in November 2005. Individual cows were monitored from $60 \mathrm{~d}$ before the expected calving date until $60 \mathrm{~d}$ after calving. Heifers were fitted with a ruminal cannula (Bar Diamond, Parma, ID) between 70 and $100 \mathrm{~d}$ in gestation and were housed at the Lethbridge Research Center Dairy and Metabolism Facility (Lethbridge, Alberta, Canada). Cows were weighed on 2 consecutive days and BCS was determined (Wildman et al., 1982) prior to the start of the study, before each diet change, and on $d+17 \pm 1.2, d+37 \pm 1.4$, and $d+58 \pm 1.5$ postcalving. After parturition, cows were milked twice daily at 0630 and $1630 \mathrm{~h}$ and milk yield was recorded. Mean and standard deviation values for BW, BCS (5-point scale), and DMI at the start of the study (d $-58 \pm 4.7$ relative to parturition) were $633 \pm 52.0 \mathrm{~kg}, 3.5 \pm 0.23$, and $12.0 \pm 1.44 \mathrm{~kg} / \mathrm{d}$, respectively. All procedures were approved by the Lethbridge Research Center Animal Care Committee and were in accordance with the guidelines of the Canadian Council of Animal Care (Ottawa, Ontario, Canada).

\section{Experimental Treatments}

Heifers were paired by expected calving date and BCS and assigned to: 1) control treatment consisting of a far-off diet (forage:concentrate, $\mathbf{F}: \mathbf{C}=81: 19$ ) fed from $d-60$ to $d-25$ and a close-up $\operatorname{diet}(\mathrm{F}: \mathrm{C}=54: 46)$ fed from d-24 until parturition; or 2) a high-concentrate (HC) feeding program consisting of 4 prepartum diets, $\mathrm{HC}-1$ ( $\mathrm{F}: \mathrm{C}=68: 32$ ) fed from $\mathrm{d}-60$ to $\mathrm{d}-43, \mathrm{HC}-2$ ( $\mathrm{F}: \mathrm{C}=$ 59:41) fed from $d-42$ to $d-25, \mathrm{HC}-3(\mathrm{~F}: \mathrm{C}=52: 48)$ fed from $\mathrm{d}-24$ to $\mathrm{d}-13$, and $\mathrm{HC}-4(\mathrm{~F}: \mathrm{C}=47: 53)$ fed from $\mathrm{d}-12$ until parturition. All cows received the same lactation diet postpartum. The control treatment was designed to reflect the NRC (2001) recommendations for transitioning a heifer from a nonlactating pregnant state to a nonpregnant lactating state. In contrast, the $\mathrm{HC}$ treatment was designed to provide additional energy prepartum by increasing the proportion of concentrate. The pelleted concentrate used for the HC treatment included ground barley grain and nonforage fiber sources such as wheat middlings, dried beet pulp, and dry corn distillers grains (Table 1). Diets HC-1 and HC2 were formulated to have $\mathrm{CP}$ contents similar to the far-off control diet, whereas diets HC-3 and HC-4 were formulated to have CP contents similar to the close-up control diet. The F:C ratio of the $\mathrm{HC}$ diets was altered by decreasing the proportion of barley silage and grass hay (the ratio of barley silage to grass hay was maintained) and increasing the proportion of nonforage fiber sources (wheat middlings, dried beet pulp, and dried distillers grains) and barley grain. Diets were formulated using the Cornell-Penn-Miner System (cpm Dairy, Version 3.0.4a; University of Pennsylvania, Ken- 
Table 1. Ingredient composition of the experimental diets (DM basis)

\begin{tabular}{|c|c|c|c|c|c|c|c|}
\hline \multirow[b]{3}{*}{ Item } & \multicolumn{7}{|c|}{ Treatment $^{1}$} \\
\hline & \multicolumn{2}{|c|}{ Control } & \multicolumn{4}{|c|}{$\mathrm{HC}$} & \multirow{2}{*}{$\begin{array}{l}\text { Lactation } \\
\text { diet }\end{array}$} \\
\hline & Far-off & Close-up & $\mathrm{HC}-1$ & HC-2 & $\mathrm{HC}-3$ & $\mathrm{HC}-4$ & \\
\hline \multicolumn{8}{|c|}{$\begin{array}{l}\text { Ration composition, }{ }^{2} \% \text { of DM } \\
\text { Forages }\end{array}$} \\
\hline Barley silage & 69.1 & 47.0 & 58.8 & 52.2 & 45.9 & 40.6 & 42.2 \\
\hline Alfalfa hay & - & 7.2 & - & - & - & - & 4.4 \\
\hline Grass hay & 11.7 & - & 8.7 & 7.7 & 6.0 & 6.0 & - \\
\hline \multicolumn{8}{|l|}{ Concentrates } \\
\hline Steam-rolled barley grain & 6.7 & 9.1 & - & - & - & - & 28.6 \\
\hline Ground barley grain & 2.2 & 4.5 & 17.1 & 18.0 & 21.4 & 22.3 & 2.2 \\
\hline Canola meal & 5.3 & 4.5 & 5.5 & 4.2 & 5.8 & 5.5 & 1.8 \\
\hline Corn gluten meal & 1.6 & 3.6 & - & - & - & - & 2.9 \\
\hline Dry corn distillers grain & - & - & 0.4 & 0.8 & 6.4 & 4.9 & - \\
\hline Wheat middlings & - & - & 4.2 & 8.0 & 5.1 & 7.8 & - \\
\hline Beet pulp & - & 13.6 & 4.2 & 8.0 & 5.1 & 7.8 & 2.2 \\
\hline Calcium carbonate & 0.9 & 1.8 & 0.8 & 0.8 & 0.8 & 0.8 & 0.6 \\
\hline Calcium diphosphate & 0.6 & 0.7 & - & - & - & - & 0.7 \\
\hline Sodium bicarbonate & - & & - & - & - & - & 0.6 \\
\hline Magnesium oxide & - & 0.4 & - & - & - & - & 0.1 \\
\hline Megalac $^{3}$ & - & - & - & - & - & - & 2.0 \\
\hline Beet molasses & 1.3 & 0.9 & - & - & - & - & 1.7 \\
\hline Canola oil & 0.2 & 0.5 & 0.1 & 0.1 & 0.1 & 0.1 & 0.5 \\
\hline Nutrichlor ${ }^{4}$ & - & 5.9 & - & - & 3.2 & 4.0 & - \\
\hline Vitamin-mineral mix & 0.4 & 0.3 & 0.2 & 0.2 & 0.2 & 0.2 & 0.7 \\
\hline SoyPass $^{5}$ & - & - & - & - & - & - & 8.8 \\
\hline
\end{tabular}

${ }^{1}$ The control treatment consisted of a far-off diet that was fed from $d-60$ to $d-25$ and a close-up diet fed from $\mathrm{d}-24 \mathrm{~d}$ until parturition. The high concentrate $(\mathrm{HC})$ treatment consisted of 4 diets: HC- 1 was fed from $\mathrm{d}-60$ until d -43 , HC-2 was fed from d -42 until d -25 , HC-3 was fed from d -24 until d -13 , and HC-4 was fed from d -12 until parturition. Cows on both treatments received the same diet postpartum.

${ }^{2}$ Formulated to contain $0.81 \% \mathrm{Ca}, 0.41 \% \mathrm{P}, 0.23 \% \mathrm{Mg}, 1.2 \% \mathrm{~K}, 0.25 \% \mathrm{~S}, 0.30 \% \mathrm{Na}, 1.0 \% \mathrm{Cl}, 145 \mathrm{ppm}$ of $\mathrm{Fe}, 60 \mathrm{ppm}$ of $\mathrm{Zn}, 18 \mathrm{ppm}$ of Cu, $53 \mathrm{ppm}$ of Mn, $0.3 \mathrm{ppm}$ of Se, $0.6 \mathrm{ppm}$ of Co, $0.3 \mathrm{ppm}$ of I, $8.3 \mathrm{kIU} / \mathrm{kg}$ of vitamin A, $1.3 \mathrm{KIU} / \mathrm{kg}$ of vitamin $\mathrm{D}$, and $62.7 \mathrm{IU} / \mathrm{kg}$ of vitamin $\mathrm{E}$ (DM basis).

${ }^{3}$ Megalac calcium salts of palm oil (Church and Dwight Co., Inc., Princeton, NJ).

${ }^{4}$ Nutri-tech Solutions (Abbotsford, BC, Canada).

${ }^{5}$ LignoTech USA Inc. (Rothchild, WI).

nett Square, PA, Cornell University, Ithaca, NY, and William H. Miner Agricultural Research Institute, Chazy, NY). The lactation diet was formulated to supply adequate $\mathrm{ME}$ and $\mathrm{MP}$ for a $650-\mathrm{kg}$ cow producing 35 $\mathrm{kg} / \mathrm{d}$ of milk containing $3.5 \%$ fat and $3.2 \%$ protein. The ingredient composition of diets is given in Table 1 . Weekly samples of the barley silage were collected, and the $\mathrm{DM}$ content was determined by oven drying at $55^{\circ} \mathrm{C}$ for $48 \mathrm{~h}$. Diets were adjusted over the course of the study to maintain the specified $\mathrm{F}: \mathrm{C}$ ratio on a DM basis.

Cows were fed ad libitum (10\% orts) and fresh feed was offered in equal proportions twice daily at 1330 and $1800 \mathrm{~h}$. The weight of feed offered and refused was recorded daily throughout the duration of the study. Samples of the TMR were collected once weekly with one subsample used for particle size measurement using the Penn State Particle Size Separator (Lammers et al., 1996; Kononoff et al., 2003). The second subsample of TMR was analyzed for DM content and stored for later chemical analysis. Daily ort samples were col- lected and a weekly composite by cow was analyzed for DM.

The weekly TMR samples were composited by 3-mo periods and the composite samples were analyzed for chemical composition. The analytical DM content was determined by oven drying at $135^{\circ} \mathrm{C}$ for $2 \mathrm{~h}$ (AOAC, 1990). Ash content was determined by combustion at $550^{\circ} \mathrm{C}$ for $6 \mathrm{~h}$. The $\mathrm{OM}$ content was calculated as the difference between DM and ash. The nitrogen content for $\mathrm{CP}$ calculation $(\mathrm{CP}=\mathrm{N} \times 6.25)$ was determined by flash combustion (Carlo Erba Instruments, Milan, Italy). The NDF and ADF contents were determined sequentially using a digestion technique (model A200; Ankom Technology Corp., Fairport, NY) that included amylase and sodium sulfite for NDF as described by Van Soest et al. (1991).

\section{Ruminal Measurements}

Ruminal VFA were measured in samples of ruminal fluid collected daily from $d-5$ to $d+5$ and on 2 consecu- 
tive days starting on $\mathrm{d}+17 \pm 1.2, \mathrm{~d}+37 \pm 1.4$, and $\mathrm{d}$ $+58 \pm 1.5$ relative to parturition. Collection occurred at $1630 \mathrm{~h}$, which corresponded to $3 \mathrm{~h}$ postfeeding. In total, approximately $750 \mathrm{~mL}$ of ruminal fluid was obtained from 3 different locations in the rumen: the reticulum, the ventral sac, and the interface between the fluid phase and ruminal mat. Samples were immediately strained through perforated material (Peetex, pore size $=355 \mu \mathrm{m}$; Sefar Canada Inc., Scarborough, Ontario, Canada) and $10 \mathrm{~mL}$ of strained ruminal fluid was added to $2 \mathrm{~mL}$ of $25 \%$ metaphosphoric acid. Samples were stored at $-20^{\circ} \mathrm{C}$ for later analysis. Ruminal VFA were separated and quantified by gas chromatography (Varian 3700; Varian Specialties Ltd., Brockville, Ontario, Canada) using a $15-\mathrm{m}(0.53-\mathrm{mm}$ i.d.) fused-silica column (DB-FFAP column; J\&W Scientific, Folsom, CA).

Ruminal $\mathrm{pH}$ was continuously measured from $\mathrm{d}-5$ to $\mathrm{d}+5 \pm 0.0$, and for 3 consecutive days starting on $\mathrm{d}$ $+17 \pm 1.2, \mathrm{~d}+37 \pm 1.4$, and $\mathrm{d}+58 \pm 1.5$ relative to parturition using the Lethbridge Research Centre Ruminal pH Measurement System (LRCpH; Dascor, Escondido, CA) as described by Penner et al. (2006). Briefly, the system consisted of a watertight capsule containing a $\mathrm{pH}$ electrode and data acquisition device that was placed into the rumen of the cow. The $\mathrm{pH}$ electrode (model S650-CDHF; Sensorex, Garden Grove, CA) was covered by a shroud that allowed particle and liquid passage but kept the $\mathrm{pH}$ electrode from contacting the surface of the ruminal epithelium. The capsule was attached to the ruminal cannula plug to aid in system location within the rumen and to help maintain the electrode in a vertical position. Two $900-\mathrm{g}$ weights were fastened to the bottom of the electrode shroud to maintain the electrode in the ventral sac of the rumen. Readings in $\mathrm{pH}$ buffers 4 and 7 were recorded prior to placing the $\mathrm{LRCpH}$ system in the rumen. Ruminal $\mathrm{pH}$ readings were taken every $30 \mathrm{~s}$ and stored by the data logger (model M1b-pH-1KRTD; Dascor, Escondido, CA). After about $23.5 \mathrm{~h}$ of continuous $\mathrm{pH}$ measurement, the $\mathrm{LRCpH}$ was removed from the rumen, washed in $39^{\circ} \mathrm{C}$ water and millivolt readings were recorded in $\mathrm{pH}$ buffers 4 and 7. Electrodes and buffers were maintained at $39^{\circ} \mathrm{C}$ until the data were downloaded. The shift in millivolt readings from the electrodes between the start and finish standardization was assumed to be linear and was used to convert the millivolt data to $\mathrm{pH}$ units.

The daily ruminal $\mathrm{pH}$ data were averaged for each minute and summarized as minimum $\mathrm{pH}$, mean $\mathrm{pH}$, and maximum $\mathrm{pH}$. The occurrence and extent of $\mathrm{RA}$ was determined from the $\mathrm{pH}$ records using $3 \mathrm{pH}$ thresholds: 5.8, 5.5, and 5.2. Ruminal acidosis was considered to occur when ruminal $\mathrm{pH}$ was $<5.8$ (total $\mathrm{RA}$ ). The $\mathrm{pH}$ profiles were further characterized as mild RA when $5.8>$ ruminal $\mathrm{pH}>5.5$, moderate $\mathrm{RA}$ when $5.5>$ ruminal $\mathrm{pH}>5.2$, and acute $\mathrm{RA}$ when ruminal $\mathrm{pH}<5.2$. The thresholds 5.8, 5.5, and 5.2 were assigned because they have previously been used in our laboratory (Maekawa et al., 2002; Beauchemin and Yang, 2005) or have been defined by others (Nocek, 1997). The duration (h/d) and total area $(\mathrm{pH} \times \mathrm{min})$ that $\mathrm{pH}$ was below each threshold was calculated. In addition, the number of daily episodes of each category of RA was noted. A daily episode was defined to begin when ruminal $\mathrm{pH}$ was below the predefined threshold and to end when ruminal $\mathrm{pH}$ met or exceeded the threshold.

\section{Milk Sampling and Analysis}

Milk was sampled on 2 consecutive days starting on $\mathrm{d}+3 \pm 0.4, \mathrm{~d}+16 \pm 1.1, \mathrm{~d}+36 \pm 1.4$, and $\mathrm{d}+59 \pm 1.3$ relative to parturition to determine milk composition. Milk samples were preserved with potassium dichromate and stored at $4^{\circ} \mathrm{C}$ until sent to the Central Alberta Milk Testing Laboratory (Edmonton, Alberta, Canada). Milk was analyzed for fat, $\mathrm{CP}$, and lactose concentration using an infrared analyzer (Milk-O-Scan 605; Foss Electric, Hillerød, Denmark). Milk composition was corrected for differences in milk volume between a.m. and p.m. milkings.

\section{Blood Sampling and Analysis}

Blood was sampled from the coccygeal vein at 0900 $\mathrm{h}$ on $\mathrm{d}-49 \pm 4.9, \mathrm{~d}-14 \pm 4.1, \mathrm{~d}-7 \pm 1.2, \mathrm{~d}+7 \pm 0.4, \mathrm{~d}$ $+19 \pm 1.1$, and $d+61 \pm 1.3$ relative to parturition to assess glucose, insulin, NEFA, and BHBA concentrations. For plasma, blood was collected into a 7-mL Vacutainer containing lithium heparin (Fisher Scientific Company, Nepean, Ontario, Canada). Blood samples were centrifuged at $3,000 \times g$ for 25 min immediately after sampling. A subsample of plasma was analyzed immediately for glucose (Idex Laboratories Inc., Westbrook, ME). A second subsample of plasma was stored at $-20^{\circ} \mathrm{C}$ for analysis of insulin. Plasma was iodinated using the chloramine-T method as described by Greenwood et al. (1963). Crystalline bovine insulin (Lilly Research Laboratories, Indianapolis, IN; lot no. $615-70 \mathrm{~N}$ 80) was used as a standard. Iodinated samples were analyzed using a double antibody RIA (Brockman, 1979). For serum, blood was collected into a 7-mL Vacutainer tube containing silica gel (Fisher Scientific Company). Serum samples were chilled on ice for $30 \mathrm{~min}$ and centrifuged at 3,000 $\times$ g for $25 \mathrm{~min}$. Samples were then stored at $-20^{\circ} \mathrm{C}$ and were sent to the Animal Health Laboratory (Guelph, Ontario, Canada) for analysis of NEFA and BHBA. 


\section{Statistical Analysis}

Four cows were removed from the study because they calved early in relation to their expected calving date. This resulted in 7 cows per treatment completing the study. Data were summarized for each cow by measurement period. For DMI, only the data for $d-5$ to $d+5 \pm$ 0.0 , and for 3 consecutive days starting on $d+17 \pm 1.2$, $\mathrm{d}+37 \pm 1.4$, and $\mathrm{d}+58 \pm 1.5$ were used because these measurements corresponded to ruminal $\mathrm{pH}$, ruminal VFA, BW, BCS, and milk yield and composition measurements. For DMI, milk yield and composition, ruminal $\mathrm{pH}$, and ruminal VFA concentrations statistical analysis was performed using the PROC MIXED procedure of SAS (version 9.13; SAS Institute Inc., Cary, $\mathrm{NC}$ ), accounting for repeated measures with the random effect of cow and the fixed effect of treatment. Day within measurement period and measurement period were considered to be the repeated measures. Various variance-covariance error structures were used, depending on which error structure produced the lowest Akaike's information criterion and Bayesian information criterion values for each variable. For BW, BCS, and blood metabolite and hormone concentrations, data were analyzed using the PROC MIXED procedure of SAS (version 9.13; SAS Institute Inc.) accounting for repeated measures. Cow was considered the random effect with the fixed effect of treatment. Day of sampling was the repeated measure. All data were analyzed for the main effects of treatment and period and the interaction of treatment $\times$ period and are presented as preand postpartum means.

For ruminal $\mathrm{pH}$, data were also analyzed using the PROC MIXED procedure of SAS (version 9.13; SAS Institute Inc.) using measurement period as a regression variable to determine how day relative to parturition affected RA. Both linear and quadratic relationships were tested. Differences were considered significant when $P<0.05$ and trends are discussed when $P$ $<0.10$.

\section{RESULTS AND DISCUSSION}

\section{Experimental Diets}

The chemical composition of the experimental diets is listed in Table 2. The nonforage fiber sources were used to increase the digestible NDF fraction without providing excessive starch. The close-up diet in the control treatment had a $\mathrm{NE}_{\mathrm{L}}$ content similar to the NRC (2001) recommendations and close-up diets (fed from d -24 until parturition) in the HC treatment provided a higher $\mathrm{NE}_{\mathrm{L}}(\mathrm{Mcal} / \mathrm{kg}$ ) than the close-up control treatment. Thus, our objective of providing diets containing higher energy density to cows fed the HC treatment was achieved. Despite widely differing F:C ratios, the combined amount of feed retained on the Penn State Particle Size Separator sieves with 1.18-, 8-, and 19mm openings exceeded $90 \%$ for all diets (Table 2). The lack of variation in the proportion of feed retained by the sieves occurred because some of the concentrate, particularly the pelleted portion, was retained on the 1.18- and 8-mm sieves. All cows received the same lactation diet postpartum, which supplied $29.4 \%$ of total $\mathrm{NDF}, 20.1 \%$ of NDF from forage sources, and $43.5 \%$ of NFC (Table 2). Thus, the NRC (2001) recommendations of a minimum of $25 \%$ of total NDF, $19 \%$ of NDF from forage sources, and a maximum of $44 \%$ of NFC was met; consequently, the chemical and physical fiber supplied by the lactation diet was considered above the requirement to prevent RA (NRC, 2001; Zebeli et al., 2006).

\section{Ruminal Fermentation Characteristics}

Ruminal Acidosis. Contrary to our hypothesis, feeding additional concentrate prepartum did not reduce postpartum RA (Table 3). Previously, others have demonstrated that feeding concentrate prepartum promoted ruminal papillae proliferation with increases in length, width, and surface area (Dirksen et al., 1985). Thus, we hypothesized that increases in papillae surface area due to additional concentrate feeding prepartum would increase the capacity for VFA absorption, and thereby reduce RA. However, our results do not support this hypothesis. To our knowledge, this is the first study that has comprehensively measured ruminal $\mathrm{pH}$ and the prevalence of RA during the periparturient period. Alternatively, spot sampling techniques have been used to measure the effect of prepartum dietary treatment on ruminal pH (Dann et al., 1999; Rabelo et al., 2003); however, spot sampling techniques require a considerable amount of labor to collect ruminal $\mathrm{pH}$ measurements and measurements are therefore not taken frequently enough to adequately describe ruminal $\mathrm{pH}$ variation over an extended period of time. In the current study, ruminal $\mathrm{pH}$ was measured over several consecutive days at various times relative to parturition using continuous ruminal $\mathrm{pH}$ measurement (Penner et al., 2006) to provide comprehensive characterization of ruminal $\mathrm{pH}$ during the periparturient period and into early lactation.

Cows fed the HC treatment prepartum tended to have lower prepartum minimum $\mathrm{pH}(P=0.06$; Table 3$)$. Krause and Oetzel (2006) suggested that measurement of minimum ruminal $\mathrm{pH}$ values may improve the probability of detecting treatment differences over mean ruminal $\mathrm{pH}$ values when continuous $\mathrm{pH}$ measurement is used. Cows fed the HC treatment also had a tendency 
Table 2. Nutrient composition and particle size distribution of the experimental diets

\begin{tabular}{|c|c|c|c|c|c|c|c|}
\hline \multirow[b]{3}{*}{ Item } & \multicolumn{7}{|c|}{ Treatment $^{1}$} \\
\hline & \multicolumn{2}{|c|}{ Control } & \multicolumn{4}{|c|}{$\mathrm{HC}$} & \multirow{2}{*}{$\begin{array}{l}\text { Lactation } \\
\text { diet }\end{array}$} \\
\hline & Far-off & Close-up & HC-1 & $\mathrm{HC}-2$ & $\mathrm{HC}-3$ & $\mathrm{HC}-4$ & \\
\hline \multicolumn{8}{|l|}{ Chemical composition } \\
\hline $\mathrm{DM}, \%$ & 50.4 & 56.5 & 59.3 & 59.2 & 63.2 & 63.7 & 57.5 \\
\hline $\mathrm{OM}, \%$ of $\mathrm{DM}$ & 91.3 & 91.2 & 92.3 & 92.6 & 92.6 & 92.3 & 91.5 \\
\hline $\mathrm{CP}, \%$ of DM & 14.0 & 16.7 & 14.9 & 14.9 & 17.8 & 16.4 & 17.3 \\
\hline $\mathrm{NDF}, \%$ of DM & 36.4 & 31.3 & 33.2 & 33.7 & 30.6 & 30.4 & 29.4 \\
\hline Forage NDF, \% of NDF & 87.4 & 74.6 & 92.3 & 80.4 & 76.7 & 69.6 & 68.4 \\
\hline $\mathrm{ADF}, \%$ of $\mathrm{DM}$ & 19.2 & 18.3 & 16.9 & 16.9 & 15.6 & 15.5 & 15.6 \\
\hline $\mathrm{NFC}^{2} \%$ of $\mathrm{DM}$ & 39.6 & 42.5 & 43.3 & 43.1 & 43.4 & 44.9 & 43.5 \\
\hline Predicted $\mathrm{NE}_{\mathrm{L}},{ }^{3} \mathrm{Mcal} / \mathrm{kg}$ & 1.41 & 1.50 & 1.53 & 1.55 & 1.58 & 1.59 & 1.72 \\
\hline \multicolumn{8}{|c|}{ Particle size separation, ${ }^{4} \%$ of DM } \\
\hline$>19 \mathrm{~mm}$ & 23.35 & 12.52 & 17.91 & 14.74 & 11.62 & 9.85 & 10.57 \\
\hline 9 to $19 \mathrm{~mm}$ & 36.46 & 47.11 & 47.24 & 51.86 & 55.65 & 65.93 & 40.72 \\
\hline 1.18 to $8 \mathrm{~mm}$ & 35.68 & 36.27 & 30.79 & 29.49 & 27.95 & 21.05 & 42.38 \\
\hline$<1.18 \mathrm{~mm}$ & 4.52 & 4.10 & 4.06 & 3.92 & 4.79 & 3.17 & 6.33 \\
\hline
\end{tabular}

${ }^{1}$ The control treatment consisted of a far-off diet that was fed from d -60 to $\mathrm{d}-25$ and a close-up diet fed from $\mathrm{d}-24 \mathrm{~d}$ until parturition. The high concentrate (HC) treatment consisted of 4 diets: HC-1 was fed from $\mathrm{d}-60$ until d -43 , HC-2 was fed from d -42 until d -25 , HC-3 was fed from d -24 until d -13 , and HC-4 was fed from $\mathrm{d}-12$ until parturition. Cows on both treatments received the same diet postpartum.

${ }^{2}$ Average values for ether extract and neutral detergent insoluble nitrogen were used in the calculation (NRC, 2001).

${ }^{3}$ Calculated using equations from NRC (2001).

${ }^{4}$ Determined using the Penn State Particle Size Separator (Kononoff et al., 2003).

for longer duration $(P=0.09)$ and area $(P=0.09)$ of total RA and greater area of total RA than cows fed the control treatment. This resulted in cows on the $\mathrm{HC}$ treatment spending approximately $1 \mathrm{~h} / \mathrm{d}$ more than cows on the control treatment with ruminal $\mathrm{pH}<5.8$. An interaction $(P=0.01)$ was detected for the number

Table 3. The effect of prepartum dietary treatment on ruminal acidosis in primiparous Holstein cows

\begin{tabular}{|c|c|c|c|c|c|c|c|c|}
\hline \multirow[b]{2}{*}{ Variable } & \multicolumn{4}{|c|}{ Treatment $^{1}$} & & & & \\
\hline & Prepartum & Postpartum & Prepartum & Postpartum & Prepartum & Postpartum & Treatment & Period \\
\hline Minimum pH & 5.80 & 5.37 & 5.67 & 5.36 & 0.04 & 0.03 & 0.06 & $<0.01$ \\
\hline Mean pH & 6.33 & 5.99 & 6.31 & 5.96 & 0.03 & 0.03 & 0.39 & $<0.01$ \\
\hline Maximum $\mathrm{pH}$ & 6.86 & 6.65 & 6.88 & 6.59 & 0.03 & 0.02 & 0.51 & $<0.01$ \\
\hline \multicolumn{9}{|l|}{ Total RA } \\
\hline \multicolumn{9}{|l|}{ Mild RÁ } \\
\hline Daily episodes ${ }^{2}$ & 2.0 & 11.3 & 4.9 & 10.2 & 0.8 & 0.8 & 0.23 & $<0.01$ \\
\hline Duration, h/d & 0.5 & 4.2 & 1.2 & 4.5 & 0.2 & 0.4 & 0.14 & $<0.01$ \\
\hline Area, $\mathrm{pH} \times \min$ & 570.2 & $2,196.4$ & 957.7 & $4,241.3$ & 331.2 & 958.1 & 0.09 & $<0.01$ \\
\hline \multicolumn{9}{|l|}{ Severe RA } \\
\hline Daily episodes & 0.5 & 5.2 & 0.7 & 5.6 & 0.3 & 0.7 & 0.54 & $<0.01$ \\
\hline Duration, h/d & 0.2 & 2.3 & 0.3 & 2.7 & 0.1 & 0.3 & 0.40 & $<0.01$ \\
\hline Area, $\mathrm{pH} \times \min$ & 0.01 & 3.8 & 0.01 & 10.6 & 0.001 & 2.9 & 0.10 & $<0.01$ \\
\hline
\end{tabular}

${ }^{1}$ The control treatment consisted of a far-off diet that was fed from $\mathrm{d}-60$ to $\mathrm{d}-25$ and a close-up diet fed from $\mathrm{d}-24 \mathrm{~d}$ until parturition. The high concentrate (HC) treatment consisted of 4 diets: HC- 1 was fed from d -60 until d -43 , HC- 2 was fed from d -42 until d -25 , HC3 was fed from d -24 until d -13 , and HC-4 was fed from d -12 until parturition. Cows on both treatments received the same diet postpartum.

${ }^{2}$ Significant treatment $\times$ period interaction $(P=0.01)$.

${ }^{3}$ Significant treatment $\times$ period interaction $(P=0.02)$.

${ }^{4}$ Significant treatment $\times$ period interaction $(P<0.01)$. 
of daily episodes of severe RA. Cows fed the HC treatment had a greater number of daily episodes of mild RA before calving but fewer episodes after calving than the control treatment. There were no differences for the duration or area of mild RA. There was a tendency $(P=$ 0.09 ) for cows fed the HC treatment to have a greater duration of moderate RA than cows fed the control treatment, indicating increased severity of RA. Acute RA rarely occurred prepartum; however, cows fed additional concentrate prepartum had a greater increase postpartum in the number and duration of daily episodes of acute RA when compared with the control treatment, resulting in significant treatment $\times$ period interactions ( $P=0.02$ and 0.01 , respectively). The results of the current study are not supported by previous studies in which cows were fed additional dietary energy prepartum. For example, Rabelo et al. (2003) used rumenocentesis to collect ruminal fluid samples in cows fed prepartum diets containing high or low energy densities and observed no effect of prepartum diet on postpartum ruminal pH. Dann et al. (1999) also reported no effect of prepartum dietary treatment on postpartum ruminal $\mathrm{pH}$. However, in the previous studies, spot sampling techniques were used and ruminal fluid was collected only once postpartum (Rabelo et al., 2003) or over a 24$\mathrm{h}$ period with minimum sampling intervals of $2 \mathrm{~h}$ (Dann et al., 1999). Thus, differing results between the current study and previous studies may be related to the method and frequency of ruminal $\mathrm{pH}$ measurement.

As expected, the severity of RA was higher postpartum than prepartum, as indicated by the duration and area of total RA (Table 3). Furthermore, RA was affected by day relative to parturition (Table 4). In fact, the dietary change at parturition induced RA to a similar extent as in previous studies (Keunen et al., 2002; Osborne et al., 2004; Gozho et al., 2005). The RA observed postpartum was not, however, as severe as would be expected had cows been subjected to a grain challenge typically used to induce severe RA (Krause and Oetzel, 2005). In the current study, prepartum cows ( $d-5$ to $d-1$ relative to parturition; Table 4 ) had ruminal $\mathrm{pH}$ below 5.5 for $1.2 \mathrm{~h} / \mathrm{d}$, but the duration increased to $3.8 \mathrm{~h} / \mathrm{d}$ below ruminal $\mathrm{pH} 5.5$ following parturition $(\mathrm{d}+1$ to +5 relative to parturition; Table 4$)$. The drastic increase in RA in the current study occurred even though DMI was much lower (pooled treatment means $=11.7 \mathrm{~kg} / \mathrm{d}$ during the first $5 \mathrm{~d}$ postpartum) than in grain-induced subacute RA studies (Keunen et al., 2002; Osborne et al., 2004; Krause and Oetzel, 2005; Gozho et al., 2005). Furthermore, RA occurred even though the lactation diet was considered to supply adequate concentrations of NDF of sufficient particle length.
Minimum, mean, and maximum $\mathrm{pH}$ decreased (quadratic effect; $P<0.01$ ) immediately after parturition, with the decrease sustained on $d+17,+37$, and +58 , after which ruminal $\mathrm{pH}$ measurements were terminated, when compared with $\mathrm{d}-5$ to -1 . The duration (quadratic effect; $P<0.01$ ) and area (linear effect; $P<$ $0.01)$ of total $\mathrm{RA}(\mathrm{pH}<5.8)$ increased following parturition with the duration of total RA decreasing from $d$ +17 to $d+58$. In all parameters measured, the severity of RA increased following parturition. We speculate that the increased severity of RA was associated with the dietary change at parturition and increasing postpartum DMI. These results support previous results by Gröhn and Bruss (1990) in which they reported the greatest number of cases of RA within the first few months after parturition. Furthermore, Krause and Oetzel (2006) reported that the occurrence of RA increased with increasing DIM up to 3 mo; however, our study does not indicate a worsening of RA with increasing DIM. The severity of RA, as indicated by time spent below ruminal $\mathrm{pH} 5.8$, observed in the current study was similar to previously reported values for primiparous cows in midlactation fed barley-based diets (Maekawa et al., 2002).

Variation in ruminal $\mathrm{pH}$ values can indicate the relative risk of RA (Bevans et al., 2005); however, high variation can also mask treatment differences. In the current study, substantial variation (as indicated by high SEM) was associated with daily ruminal $\mathrm{pH}$ parameters near parturition. Furthermore, our study indicates that animal variability is higher around parturition than later in lactation, suggesting an increased risk for RA during this period. For example, from Table 4, the SEM for the area of total RA for the first $5 \mathrm{~d}$ before until $5 \mathrm{~d}$ after parturition accounted for $25 \%$ of the mean, compared with approximately $20 \%$ of the mean for the average of $d+17,+37$, and +58 . Measurements conducted near calving are inherently fraught with a high degree of variability (Drackley, 1999), hindering the probability of detecting differences between treatments. Additionally, a high degree of animal variability is also common when measuring ruminal $\mathrm{pH}$ during dietary adaptation (Bevans et al., 2005), further reducing the probability of detecting treatment differences. In addition to variation between treatments, variability within treatment was large for all ruminal $\mathrm{pH}$ variables, especially the area of total $\mathrm{RA}$. It remains puzzling why some cows within a treatment are better able to cope with diet change than others, but these differences among cows may be related to the sorting of feed, number of meals, eating rate within a meal, and salivation rate, among other factors.

Ruminal VFA Concentration. Prepartum dietary treatment did not affect the total ruminal VFA concen- 
PENNER ET AL.

Table 4. The effect of day relative to parturition on ruminal acidosis (RA) in primiparous Holstein cows

\begin{tabular}{|c|c|c|c|c|c|c|c|}
\hline \multirow[b]{2}{*}{ Variable } & \multicolumn{5}{|c|}{ Day relative to parturition } & \multicolumn{2}{|c|}{$P$-value } \\
\hline & -5 to -1 & +1 to +5 & +17 & +37 & +58 & Linear & Quadratic \\
\hline \multirow{2}{*}{$\begin{array}{l}\text { Minimum } \mathrm{pH} \\
\text { SEM }\end{array}$} & $5.74^{\mathrm{a}}$ & $5.38^{\mathrm{b}}$ & $5.37^{\mathrm{b}}$ & $5.32^{\mathrm{b}}$ & $5.37^{\mathrm{b}}$ & $<0.01$ & $<0.01$ \\
\hline & 0.02 & 0.04 & 0.04 & 0.04 & 0.04 & & \\
\hline \multirow{2}{*}{$\begin{array}{l}\text { Mean pH } \\
\text { SEM }\end{array}$} & $6.32^{\mathrm{a}}$ & $5.96^{\mathrm{b}}$ & $5.95^{\mathrm{b}}$ & $5.96^{\mathrm{b}}$ & $6.03^{\mathrm{b}}$ & $<0.01$ & $<0.01$ \\
\hline & 0.02 & 0.04 & 0.04 & 0.04 & 0.04 & & \\
\hline \multirow{2}{*}{$\begin{array}{l}\text { Maximum } \mathrm{pH} \\
\text { SEM }\end{array}$} & $6.87^{\mathrm{a}}$ & $6.62^{b}$ & $6.63^{\mathrm{b}}$ & $6.59^{\mathrm{b}}$ & $6.62^{\mathrm{b}}$ & $<0.01$ & $<0.01$ \\
\hline & 0.02 & 0.04 & 0.03 & 0.03 & 0.04 & & \\
\hline \multicolumn{8}{|l|}{ Total RA } \\
\hline \multirow{2}{*}{$\begin{array}{l}\text { Duration, h/d } \\
\text { SEM }\end{array}$} & $1.1^{\mathrm{c}}$ & $7.3^{\mathrm{ab}}$ & $9.0^{\mathrm{a}}$ & $8.3^{\mathrm{ab}}$ & $6.1^{\mathrm{b}}$ & $<0.01$ & $<0.01$ \\
\hline & 0.3 & 0.9 & 1.0 & 1.2 & 0.9 & & \\
\hline \multirow{2}{*}{$\begin{array}{l}\text { Area, } \mathrm{pH} \times \min \\
\text { SEM }\end{array}$} & $766.1^{\mathrm{b}}$ & $9,221.5^{\mathrm{a}}$ & $139.9^{\mathrm{c}}$ & $146.4^{\mathrm{c}}$ & $99.7^{\mathrm{c}}$ & $<0.01$ & 0.87 \\
\hline & 235.1 & $1,788.2$ & 20.6 & 27.1 & 23.8 & & \\
\hline \multicolumn{8}{|l|}{ Mild RA } \\
\hline \multirow{2}{*}{$\begin{array}{l}\text { Daily episodes }{ }^{1} \\
\text { SEM }\end{array}$} & $3.4^{\mathrm{b}}$ & $9.5^{\mathrm{a}}$ & $10.5^{\mathrm{a}}$ & $12.5^{\mathrm{a}}$ & $11.2^{\mathrm{a}}$ & $<0.01$ & $<0.01$ \\
\hline & 0.5 & 1.0 & 1.0 & 1.1 & 1.3 & & \\
\hline \multirow{2}{*}{$\begin{array}{l}\text { Duration, h/d } \\
\text { SEM }\end{array}$} & $0.9^{c}$ & $3.6^{\mathrm{b}}$ & $5.4^{\mathrm{a}}$ & $4.8^{\mathrm{ab}}$ & $3.9^{\mathrm{b}}$ & $<0.01$ & $<0.01$ \\
\hline & 0.2 & 0.4 & 0.6 & 0.7 & 0.5 & & \\
\hline \multirow{2}{*}{$\begin{array}{l}\text { Area, } \mathrm{pH} \times \min \\
\text { SEM }\end{array}$} & $764.0^{\mathrm{b}}$ & $9,163.0^{\mathrm{a}}$ & $109.2^{\mathrm{c}}$ & $103.4^{\mathrm{c}}$ & $70.7^{\mathrm{c}}$ & $<0.01$ & 0.91 \\
\hline & 234.2 & $1,773.1$ & 15.0 & 17.0 & 13.6 & & \\
\hline \multicolumn{8}{|l|}{ Moderate RA } \\
\hline \multirow{2}{*}{$\begin{array}{l}\text { Daily episodes } \\
\text { SEM }\end{array}$} & $0.6^{\mathrm{c}}$ & $4.1^{\mathrm{b}}$ & $7.5^{\mathrm{a}}$ & $6.3^{\mathrm{ab}}$ & $4.6^{\mathrm{ab}}$ & $<0.01$ & $<0.01$ \\
\hline & 0.2 & 0.7 & 1.3 & 1.0 & 0.9 & & \\
\hline \multirow{2}{*}{$\begin{array}{l}\text { Duration, h/d } \\
\text { SEM }\end{array}$} & $0.3^{\mathrm{c}}$ & $2.4^{\mathrm{ab}}$ & $3.2^{\mathrm{a}}$ & $2.7^{\mathrm{ab}}$ & $1.7^{\mathrm{b}}$ & $<0.01$ & $<0.01$ \\
\hline & 0.1 & 0.5 & 0.5 & 0.5 & 0.4 & & \\
\hline \multirow{2}{*}{$\begin{array}{l}\text { Area, } \mathrm{pH} \times \min \\
\text { SEM }\end{array}$} & $2.1^{\mathrm{b}}$ & $44.7^{\mathrm{a}}$ & $28.9^{\mathrm{a}}$ & $38.4^{\mathrm{a}}$ & $24.5^{\mathrm{a}}$ & $<0.01$ & $<0.01$ \\
\hline & 0.9 & 10.8 & 5.8 & 9.7 & 8.6 & & \\
\hline \multicolumn{8}{|l|}{ Acute RA } \\
\hline Daily episodes & $0.1^{\mathrm{b}}$ & $1.8^{\mathrm{a}}$ & $1.0^{\mathrm{a}}$ & $2.1^{\mathrm{a}}$ & $1.4^{\mathrm{ab}}$ & $<0.001$ & 0.16 \\
\hline SEM & 0.1 & 1.8 & 1.0 & 2.1 & 1.0 & & \\
\hline Duration, h/d & $0.0^{\mathrm{c}}$ & $1.4^{\mathrm{a}}$ & $0.4^{\mathrm{bc}}$ & $0.9^{\mathrm{ab}}$ & $0.6^{\mathrm{bc}}$ & 0.05 & 0.28 \\
\hline SEM & 0.0 & 0.5 & 0.2 & 0.3 & 0.3 & & \\
\hline Area ${ }^{2} \mathrm{pH} \times \min$ & $0.0^{\mathrm{e}}$ & $13.8^{\mathrm{a}}$ & $1.7^{\mathrm{d}}$ & $4.7^{\mathrm{b}}$ & $4.4^{\mathrm{c}}$ & 0.01 & 0.76 \\
\hline SEM & 0.0 & 5.7 & 0.8 & 1.6 & 2.3 & & \\
\hline
\end{tabular}

${ }^{a-e}$ Means with different superscripts in the same row are different $(P<0.05)$.

${ }^{1}$ Significant treatment $\times$ period interaction $(P=0.04)$.

${ }^{2}$ Significant treatment $\times$ period interaction $(P<0.01)$.

tration or individual VFA molar proportions, with the exception of butyrate (Table 5). However, the total VFA concentration increased after parturition when compared with prepartum $(P<0.01)$. Rabelo et al. (2003) observed no effect of dietary treatment on total ruminal VFA concentration or individual VFA molar propor- tions when additional concentrate was fed prepartum (Rabelo et al., 2003). A significant interaction was observed between treatment and period (pre- and postpartum) for the molar proportion of butyrate $(P=0.02)$. This was a result of cows fed the $\mathrm{HC}$ treatment having higher molar proportions of butyrate prepartum but

Table 5. The effect of prepartum dietary treatment on ruminal VFA profiles in primiparous Holstein cows

\begin{tabular}{|c|c|c|c|c|c|c|c|c|}
\hline \multirow[b]{3}{*}{ Variable } & \multicolumn{4}{|c|}{ Treatment $^{1}$} & & & & \\
\hline & \multicolumn{2}{|c|}{ Control } & \multicolumn{2}{|c|}{$\mathrm{HC}$} & \multicolumn{2}{|c|}{ SEM } & \multicolumn{2}{|c|}{$P$-value } \\
\hline & Prepartum & Postpartum & Prepartum & Postpartum & Prepartum & Postpartum & Treatment & Period \\
\hline Total VFA, mmol/L & 108.2 & 117.3 & 107.0 & 122.3 & 2.3 & 1.5 & 0.31 & $<0.01$ \\
\hline Acetate:propionate & 3.67 & 2.68 & 3.47 & 2.75 & 0.07 & 0.07 & 0.34 & $<0.01$ \\
\hline Acetate, $\mathrm{mmol} / 100 \mathrm{~mol}$ & 66.36 & 61.15 & 64.97 & 61.57 & 0.28 & 0.43 & 0.18 & $<0.01$ \\
\hline Propionate, $\mathrm{mmol} / 100 \mathrm{~mol}$ & 18.24 & 23.69 & 18.92 & 23.49 & 0.28 & 0.51 & 0.57 & $<0.01$ \\
\hline
\end{tabular}

${ }^{1}$ The control treatment consisted of a far-off diet that was fed from $d-60$ to $d-25$ and a close-up diet fed from $d-24 \mathrm{~d}$ until parturition. The high concentrate (HC) treatment consisted of 4 diets: HC- 1 was fed from d -60 until d -43 , HC- 2 was fed from d -42 until d -25, HC3 was fed from $d-24$ until d -13 , and HC-4 was fed from d -12 until parturition. Cows on both treatments received the same diet postpartum.

${ }^{2}$ Significant treatment $\times$ period interaction $(P=0.02)$. 
Table 6. The effect of prepartum dietary treatment on DMI, BW, BCS, milk production, and milk composition in periparturient primiparous Holstein cows

\begin{tabular}{|c|c|c|c|c|c|c|c|c|}
\hline \multirow[b]{2}{*}{ Variable } & \multicolumn{4}{|c|}{ Treatment $^{1}$} & & & & \\
\hline & Prepartum & Postpartum & Prepartum & Postpartum & Prepartum & Postpartum & Treatment & Period \\
\hline $\mathrm{BW}, \mathrm{kg}$ & 684 & 584 & 692 & 580 & 16 & 6 & 0.80 & $<0.01$ \\
\hline BCS & 3.8 & 2.9 & 3.8 & 2.8 & 0.1 & 0.04 & 0.27 & $<0.01$ \\
\hline Milk yield, kg/d & - & 30.43 & - & 29.01 & - & 1.13 & 0.38 & - \\
\hline Fat, $\%$ & - & 3.92 & - & 3.91 & - & 0.21 & 0.98 & - \\
\hline $\mathrm{CP}, \%$ & - & 3.08 & - & 3.19 & - & 0.07 & 0.29 & - \\
\hline Lactose, \% & - & 4.59 & - & 4.68 & - & 0.06 & 0.34 & - \\
\hline
\end{tabular}

${ }^{1}$ The control treatment consisted of a far-off diet that was fed from $\mathrm{d}-60$ to $\mathrm{d}-25$ and a close-up diet fed from $\mathrm{d}-24 \mathrm{~d}$ until parturition. The high concentrate (HC) treatment consisted of 4 diets: HC- 1 was fed from d -60 until d -43, HC-2 was fed from d -42 until d -25, HC3 was fed from d -24 until $d-13$, and HC-4 was fed from $d-12$ until parturition. Cows on both treatments received the same diet postpartum.

${ }^{2}$ Prepartum DMI is for the last $5 \mathrm{~d}$ of gestation.

similar concentrations postpartum. Prepartum diets for the HC treatment were formulated to increase ruminal production of butyrate because butyrate has been implicated as driving ruminal papillae proliferation (Dirksen et al., 1985).

\section{DMI, BW, BCS, and Lactational Performance}

Cows fed the HC treatment had lower DMI $(P=0.01)$ than the control treatment during the last $5 \mathrm{~d}$ of gestation but postpartum DMI was similar $(P>0.05$; Table 6 and Figure 1). Similar postpartum DMI was a result of cows on the HC treatment having a tendency for a higher rate $(P=0.09)$ of DMI increase during the first 21 d postpartum (173\%) when compared with the control treatment (139\%). Drastic changes in DMI corresponding to increases in dietary concentrate predispose cows to RA (Nocek, 1997). Thus, strategies that minimize the prepartum reduction in DMI and regulate the rate of DMI increase postpartum may reduce RA postpartum.

Others have reported higher prepartum DMI and similar postpartum DMI for cows fed additional concentrate prepartum (Halcomb et al., 2001; Rabelo et al., 2003) compared with cows fed lower levels of concentrate prepartum. However, the previously reported studies measured DMI continuously for $28 \mathrm{~d}$ before parturition, whereas the current study focused on DMI for

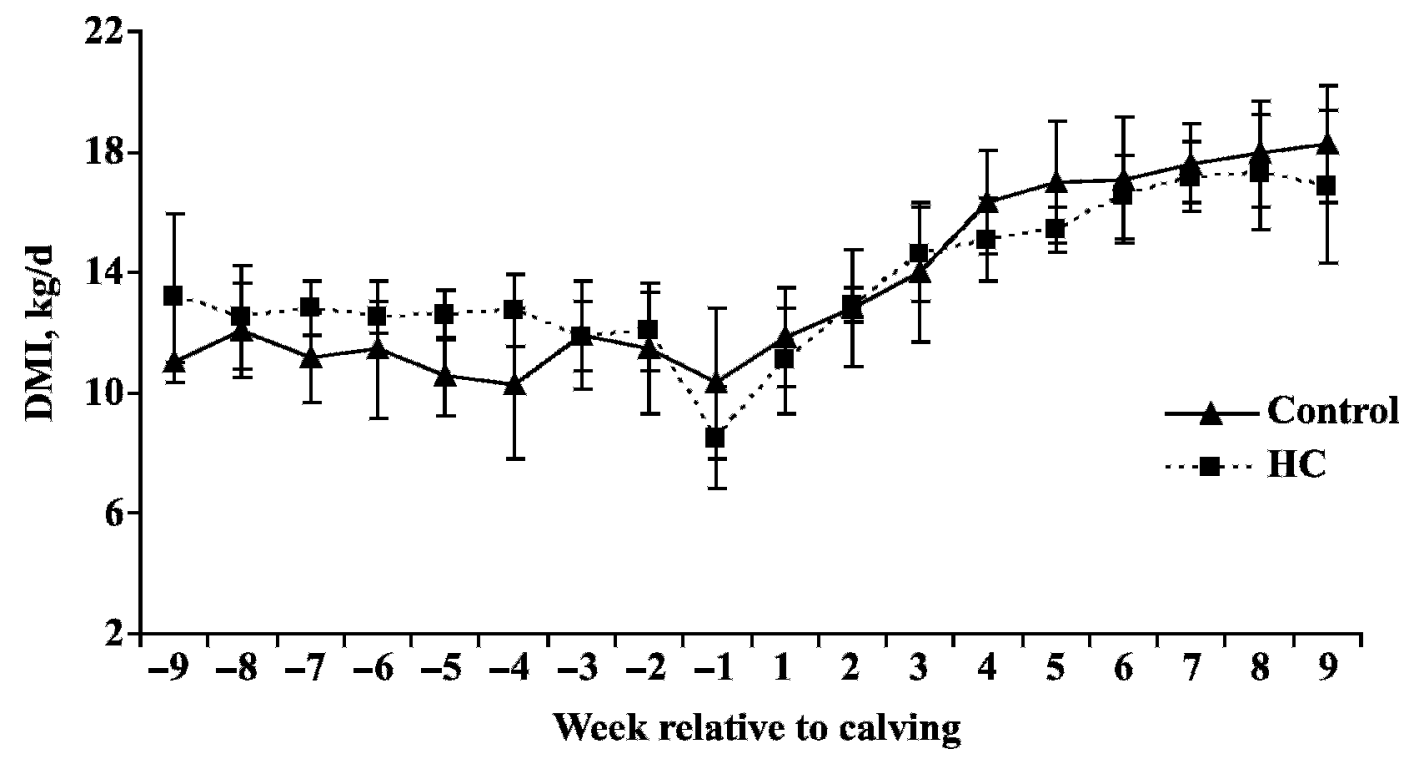

Figure 1. Weekly DMI for periparturient primiparous Holstein cows fed the control or a high concentrate (HC) feeding program. 


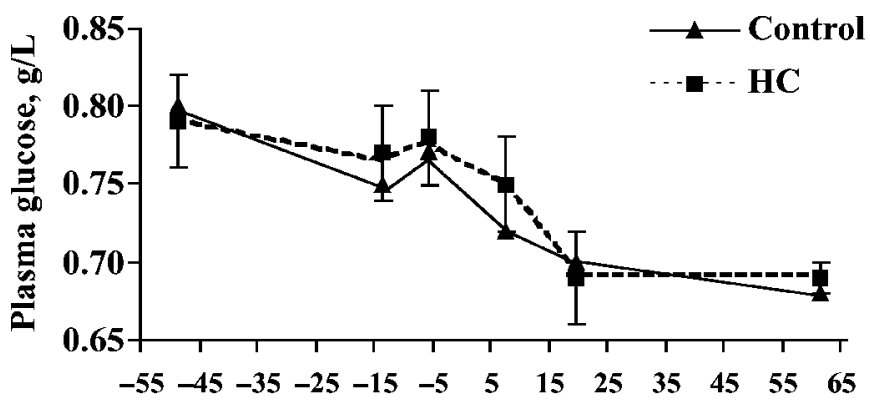

Day relative to parturition

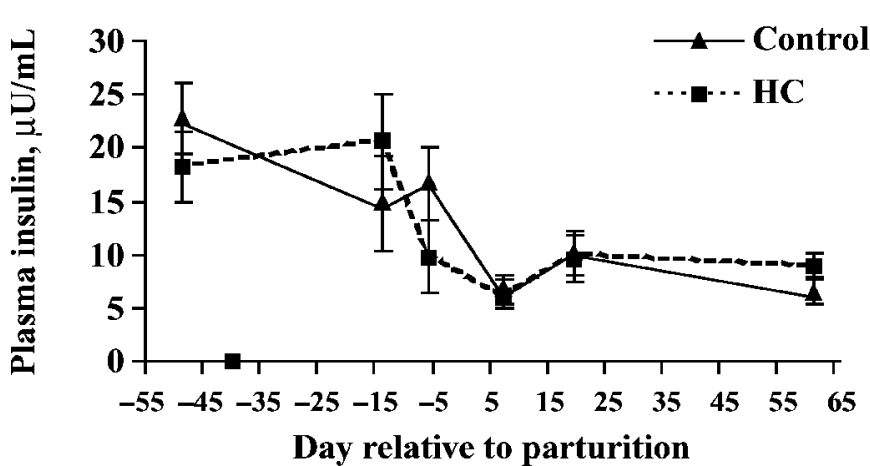

Figure 2. Plasma glucose and insulin concentrations in periparturient primiparous Holstein cows fed the control or a high concentrate (HC) feeding program.

only the last $5 \mathrm{~d}$ before parturition and at various times postpartum. We speculate that increased episodes of prepartum RA contributed to the reduction in DMI for the HC treatment when compared with the control treatment. Previously, Brown et al. (2000) reported reductions in DMI when steers were challenged with either a subacute or acute RA treatment, which supports our speculation.

Feeding additional concentrate prepartum did not improve milk yield or alter milk composition. Others have found similar results. For example, Rabelo et al. (2003) fed cows a low-energy or high-energy prepartum diet and did not observe any prepartum dietary effects on milk yield, component yield, or milk composition. Alternatively, McNamara et al. (2003) fed 3 different prepartum diets varying in $\mathrm{F}: \mathrm{C}$ ratio and energy density and observed that diets higher in energy density and lower in $\mathrm{F}$ : $\mathrm{C}$ ratio resulted in increased milk yield. However, it is noteworthy that unlike our study, McNamara et al. (2003) fed transition diets containing higher levels of forage.

\section{Blood Metabolites and Hormones}

There were no effects of dietary treatment on glucose, BHBA, NEFA, or insulin concentrations $(P>0.05$; Fig-
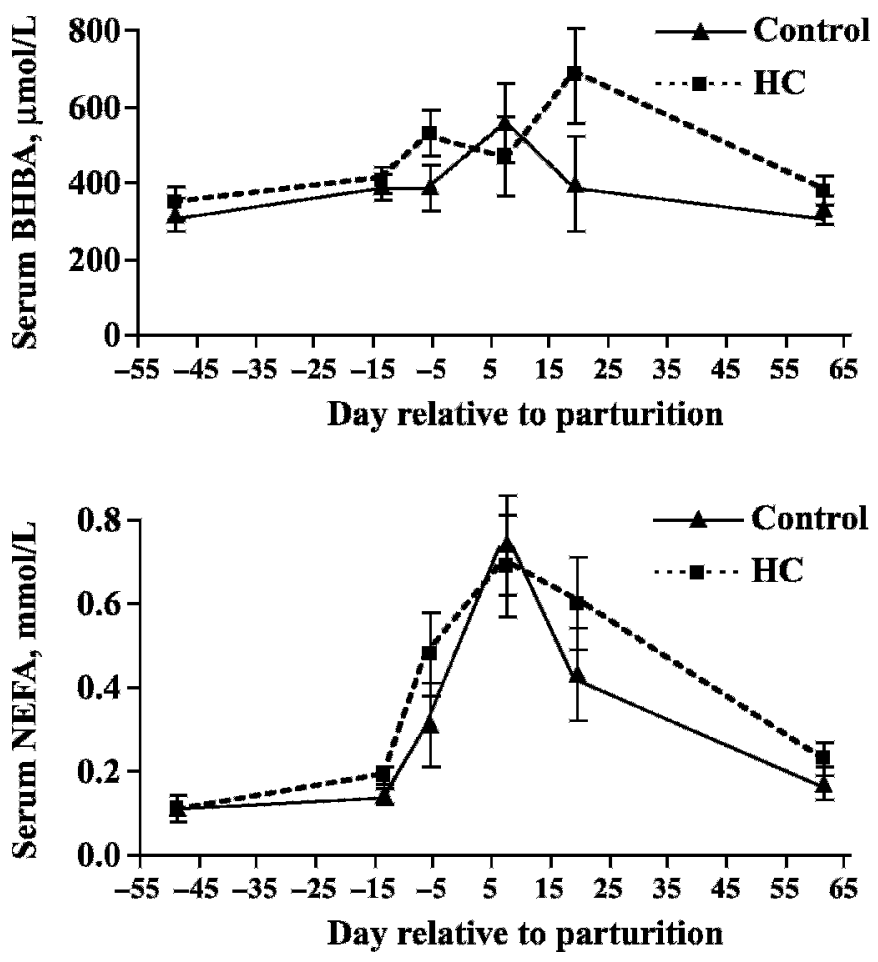

Figure 3. Serum NEFA and BHBA concentrations in periparturient primiparous Holstein cows fed the control or a high concentrate (HC) feeding program.

ures 2 and 3). Other studies have reported that prepartum treatment did not affect postpartum glucose or insulin concentrations (Dann et al., 1999; Rabelo et al., 2005). However, Dann et al. (1999) found a decrease in prepartum NEFA and BHBA concentrations when diets contained higher levels of ruminally degradable carbohydrate. The lack of a treatment effect for NEFA in the current study suggests that feeding additional concentrate prepartum did not improve energy balance or reduce adipose tissue mobilization around parturition.

\section{CONCLUSIONS}

Feeding additional concentrate prepartum did not reduce the risk of postpartum RA in primiparous Holstein cows. Furthermore, the occurrence and severity of RA increased immediately postpartum, regardless of the prepartum diet. Postpartum RA may have negative implications for animal health, fiber digestion, and nutrient supply, thus exacerbating the effects of the negative energy balance in early-lactation cows. Results of this study emphasize the importance of developing new feeding strategies that reduce the risk of RA near parturition. 


\section{ACKNOWLEDGMENTS}

The authors thank Bev Farr and Chase Wendorff for their assistance with $\mathrm{pH}$ measurement and ruminal fluid sample collection. Toby Entz is acknowledged for his advice and assistance with the statistical analysis. Gratitude is extended to Darrell Vedres for assistance with gas chromatography. Finally, we thank the farm staff at the Lethbridge Research Centre for preparing the diets and for other general animal husbandry duties.

\section{REFERENCES}

AOAC. 1990. Official Methods of Analysis. Vol. 1 15th ed. AOAC, Arlington, VA.

Beauchemin, K. A., and W. Z. Yang. 2005. Effects of physically effective fiber on intake, chewing activity, and ruminal acidosis for dairy cows fed diets based on corn silage. J. Dairy Sci. 88:2117-2129.

Bevans, D. W., K. A. Beauchemin, K. S. Shwartzkopf-Genswein, J. J. McKinnon, and T. A. McAllister. 2005. Effect of rapid or gradual grain adaptation on subacute acidosis and feed intake by feedlot cattle. J. Anim. Sci. 83:1116-1132.

Brockman, R. P. 1979. Glucagon responses to exercise in sheep. J. Biol. Sci. 32:215-220.

Brown, M. S., C. R. Krehbiel, M. L. Galyean, M. D. Remmenga, J. P. Peters, B. Hibbard, J. Robinson, and W. M. Moseley. 2000. Evaluation of models of acute and subacute acidosis on dry matter intake, ruminal fermentation, blood chemistry, and endocrine profiles of beef steers. J. Anim. Sci. 78:3155-3168.

Dann, H. M., G. A. Varga, and D. E. Putnam. 1999. Improving energy supply to late gestation and early postpartum dairy cows. J. Dairy Sci. 82:1765-1778.

Dirksen, G. U., H. G. Liebich, and E. Mayer. 1985. Adaptive changes of the ruminal mucosa and their functional and clinical significance. Bovine Pract. 20:116-120.

Drackley, J. K. 1999. Biology of dairy cows during the transition period: The final frontier. J. Dairy Sci. 82:2259-2273.

Gozho, G. N., J. C. Plaizier, D. O. Krause, A. D. Kennedy, and K. M. Wittenberg. 2005. Subacute ruminal acidosis induces ruminal lipopolysaccharide endotoxin release and triggers an inflammatory response. J. Dairy Sci. 88:1399-1403.

Greenwood, F. C., W. M. Hunter, and J. S. Glover. 1963. The preparation of ${ }^{131}$ I-labelled human growth hormone of high specific radioactivity. Biochem. J. 89:114-123.

Gröhn, Y. T., and M. L. Bruss. 1990. Effect of diseases, production, and season on traumatic reticuloperitonitis and ruminal acidosis in dairy cattle. J. Dairy Sci. 73:2355-2363.

Grummer, R. R. 1995. Impact of changes in organic nutrient metabolism on feeding the transition dairy cow. J. Anim. Sci. 73:2820-2833.

Halcomb, C. S., H. H. Van Horn, H. H. Head, M. B. Hall, and C. J. Wilcox. 2001. Effects of prepartum dry matter intake and forage percentage on postpartum performance of lactating dairy cows. J. Dairy Sci. 84:2051-2058.

Hayirli, A., R. R. Grummer, E. V. Nordheim, and P. M. Crump. 2003. Models for predicting dry matter intake of Holsteins during the prefresh transition period. J. Dairy Sci. 86:1771-1779.
Keunen, J. E., J. C. Plaizier, L. Kyriazakis, T. F. Duffield, T. M. Widowski, M. I. Lindinger, and B. W. McBride. 2002. Effects of a subacute ruminal acidosis model on the diet selection of dairy cows. J. Dairy Sci. 85:3304-3313.

Kononoff, P. J., A. J. Heinrichs, and D. R. Buckmaster. 2003. Modification of the Penn State Forage and Total Mixed Ration Particle Size Separator and the effects of moisture content on its measurements. J. Dairy Sci. 86:1858-1863.

Krause, K. M., and G. R. Oetzel. 2005. Inducing subacute ruminal acidosis in lactating dairy cows. J. Dairy Sci. 88:3633-3639.

Krause, K. M., and G. R. Oetzel. 2006. Understanding and preventing subacute ruminal acidosis in dairy herds: a review. Anim. Feed Sci. Technol. 126:215-236.

Lammers, B. P., D. R. Buckmaster, and A. J. Heinrichs. 1996. A simple method for the analysis of particle sizes of forage and total mixed rations. J. Dairy Sci. 79:922-928.

Maekawa, M., K. A. Beauchemin, and D. A. Christensen. 2002. Chewing activity, saliva production, and ruminal $\mathrm{pH}$ of primiparous and multiparous lactating dairy cows. J. Dairy Sci. 85:1176-1182.

McNamara, S., F. P. O'Mara, M. Rath, and J. J. Murphy. 2003. Effects of different transition diets on dry matter intake, milk production and milk composition in dairy cows. J. Dairy Sci. 86:2397-2408.

Nocek, J. E. 1997. Bovine acidosis: Implications on laminitis. J. Dairy Sci. 80:1005-1028.

NRC (National Research Council). 2001. Nutrient Requirements of Dairy Cattle. 7th rev. ed. National Academy Press, Washington, DC.

Osborne, J. K., T. Mutsvangwa, O. Alzahal, T. F. Duffield, R. Bagg, P. Dick, G. Vessie, and B. W. McBride. 2004. Effects of monensin on ruminal forage degradability and total tract diet digestibility in lactating dairy cows during grain-induced subacute ruminal acidosis. J. Dairy Sci. 87:1840-1847.

Penner, G. B., K. A. Beauchemin, and T. Mutsvangwa. 2006. An evaluation of the accuracy and precision of a stand-alone submersible continuous ruminal $\mathrm{pH}$ measurement system. J. Dairy Sci. 89:2132-2140.

Rabelo, E., R. L. Rezende, S. J. Bertics, and R. R. Grummer. 2005. Effects of pre- and postfresh transition diets varying in dietary energy density on metabolic status of periparturient dairy cows. J. Dairy Sci. 88:4375-4383.

Rabelo, E., R. L. Rezende, S. J. Bertics, and R. R. Grummer. 2003. Effects of transition diets varying in dietary energy density on lactational performance and ruminal parameters of dairy cows. J. Dairy Sci. 86:916-925.

Tajima, K., S. Arai, K. Ogata, T. Nagamine, H. Matsui, M. Nakamura, R. I. Aminov, and Y. Benno. 2000. Rumen bacterial community transition during adaptation to high-grain diet. Anaerobe $6: 273-284$.

Van Soest, P. J., J. B. Robertson, and B. A. Lewis. 1991. Methods for dietary fiber, neutral detergent fiber and non-starch polysaccharide in relation to animal nutrition. J. Dairy Sci. 74:35833597.

Wildman, E. E., G. M. Jones, P. E. Wagner, R. L. Boman, H. F. Trout, Jr., and T. N. Lesch. 1982. A dairy cow body condition scoring system and its relationship to selected production characteristics. J. Dairy Sci. 65:495-501.

Zebeli, Q., M. Tafaj, H. Steingass, B. Metzler, and W. Drochner. 2006. Effects of physically effective fiber on digestive processes and milk fat content in early lactating dairy cows fed total mixed rations. J. Dairy Sci. 89:651-668. 